\title{
Reformulasi ijtihad dalam pembaruan hukum Islam menuju hukum nasional: Ikhtiar metodologis A. Qadri Azizy mentransformasikan fikih Timur Tengah ke Indonesia
}

\author{
Warkum Sumitro \\ Dosen Fakultas Hukum Universitas Brawijaya \\ E-mail:guswar@ub.ac.id \\ Fiqh V redian Aulia Ali \\ Staf Lembaga Kajian, Penelitian dan Pengembangan Hukum (LKP2H) Malang \\ E-mail:vredianaulia@gmail.com
}

This study is an elaboration of creative minds of A. Qodry Azizy about reformulation of ijtihad that was developed through reformation of " mazhab" and an eclecticism of national law. Researchers used a qualitative research with a research library approach through technical documentation. An offering of reformulation of ijtihad of A. Qodri Azizy motivated by social and academical anxiety about the entity of life after reformation and the probability of social changes with the momentum of GBHN1999. Therefore, it is neccesarily a Guidelines about formulations on" figh" which is suitable by the context of Indonesian. He started on the concerns of intention, an inner attitude and academical confidence in application of Islamic law through the agenda of reformation on "mazhab" and positivization of Islamic law within the framework of development of national laws.

Studi ini mengulas elaborasi pemikiran kreatif A. Qodri Azizy tentang reformulasi ijtihad yang dilancarkan melalui reformasi bermazhab dan eklektisisme hukum nasional. Peneliti menggunakan jenis penelitian kualitatif dengan pendekatan library research melalui teknik dokumentasi. Tawaran model reformulasi ijtihad A. Qodri Azizy dilatarbelakangi kegelisahan sosial-akademik akan entitas kehidupan pasca reformasi dan keniscayaan perubahan sosial dengan momentum GBHN 1999. Sehingga membutuhkan formulasi fikih yang sesuai konteks keindonesiaan. Ia bertitik tolak pada niat, sikap batin dan keyakinan akademis 
ljtihad, Jurnal Wacana Hukum Islam dan Kemanusiaan, Volume 15, No. 1, Juni 2015: 39-60

dalam menjalankan syariat Islam lewat agenda reformasi bermazhab dan positivisasi hukum Islam dalam bingkai pembangunan hukum nasional.

Keywords: Ijtihad; A. Qodri Aqiayy; Islamic Law; National law.

\section{Pendahuluan}

Islam dan legislasinya di Asia Tenggara tidak bisa diremehkan sebagai poros baru renaisans Islam dalam ingar bingar demokratisasi dan modernisasi dewasa ini. Perkembangan mutakhir hukum Islam di Asia Tenggara menggambarkan animo besar di aras lokal maupun nasional dalam kesadaran menjalankan ajaran-ajaran Islam (Tebba, 1993: 1-3). Seiring tantangan globalisasi dan hegemoni budaya, umat muslim kian berusaha mempertahankan corak dan identitas keberagamaannya. Penguatan institusi hukum Islam, seperti aspek kodifikasi dan positivisasi hukum Islam, peradilan agama, dan organisasi hukum Islam menunjukkan gejala yang menggembirakan.

Fenomena ini menjadi salah satu tanda, walaupun Islam di Asia Tenggara secara geografis periferal dari wilayah peradaban Arab, namun dari segi ajaran tidak dapat dipandang periferal dan terbelakang dari tradisi besar (great tradition) Islam (Azra, 2000: 8). Bahkan Islam Asia Tenggara merupakan salah satu konsentrasi muslim terbesar di dunia muslim.

Kondisi hukum Islam yang demikian telah melalui perkembangan di tengah dinamika sosial-politik, berhadapan pula dengan gejala kejumudan mazhab dan kebekuan ijtihad hukum Islam di Asia Tenggara, termasuk di Indonesia (Syarifuddin, 2002: 107). Terdapat kelompokkelompok 'tradisionalis' yang memiliki kekayaan khazanah fikih dan sangat apresiatif terhadap warisan khazanah pemikiran hukum Islam masa lalu, seperti dalam kitab-kitab fikih imam mazhab dan para muridnya. Namun, pada tingkat tertentu, terdapat sikap fanatisme mazhab dengan bias ideologisasi madzab yang monolitik. Karena terlalu terpaku pada kebesaran mazhab, kurang responsif terhadap perkembangan yang terjadi dalam masyarakat. Fikih menjadi doktrin agama yang sakral dan tidak tersentuh (Iqbal, 2009: 195-196).

Dewasa ini pula, sejumlah daerah di Indonesia menuntut penerapan syariah secara formal. Selain Aceh yang sudah diberikan hak otonomi, muncul gerakan pemenuhan hak untuk menerapkan syariah Islam di provinsi-provinsi lainnya. Misalnya di Sulawesi Selatan dan di beberapa kabupaten lain juga menyampaikan tuntutannya untuk menerapkan syariah. Pada 
Reformulasi ijthad dalam pembaruan hukum Islam menuju hukum nasional: ... (Warkum Sumitro)

saat yang sama, sejumlah gerakan Islam garis keras bermunculan, seperti Front Pembela Islam (FPI), Hizbut Tahrir Indonesia (HTI) dan Majelis Mujahidin Indonesia (MMI), dan paling santer dewasa ini adalah kelompok Negara Islam Irak dan Syuriah (NIIS/ISIS). Kelompok-kelompok tersebut cenderung menuntut penerapan syariah Islam secara totalitas (kaffah) sebagaimana diimajinasikan Islam Timur Tengah silam. Bahkan beberapa di antaranya acap kali menggunakan kekerasan untuk mengunggakapkan aspirasi amar ma'ruf nabi munkarnya.

Padahal, hukum Islam dituntut akomodatif terhadap persoalan umat tanpa kehilangan prinsip-prinsip dasarnya. Sebab bila tidak demikian, menurut Ahmad Rofiq, besar kemungkinan hukum Islam akan mengalami 'kemandulan fungsi' bagi kepentingan umat. Karena itu, apabila para pemikir hukum tidak memiliki kesanggupan atau keberanian untuk mereformulasi dan mengantisipasi setiap persoalan dalam masyarakat, serta mencari penyelesaian hukumnya, maka hukum Islam akan kehilangan aktualitasnya (Rofiq, 2001: 99).

Fikih Indonesia menjadi agenda penting pembaruan hukum Islam di Indonesia. Pengaruh faktor budaya kedaerahan ('urf atau 'adab) turut menjadi elan vital yang berdampak pada hasil pemikiran atau ijtihad mujtahid atau faqih (juris muslim). Oleh karena itu, di Indonesia muncul pendapat untuk menciptakan "må̧babala Indonesia”. Pendapat ini merupakan usaha menemukan hukum Islam yang sesuai dengan sosio-kultural bangsa Indonesia, yang dalam banyak hal terjadi perbedaan dengan sosio-kultural masyarakat di negara-negara Arab (Azizy, 2003: 19-20). A. Qodri Azizy adalah salah satu pemikir yang meneruskan nasab gagasan Fikih Keindonesiaan. Gagasannya terhitung segar dan berpengaruh dalam upaya menjadikan hukum Islam sebagai bahan baku dan konstruksi penting hukum Nasional yang sesuai dengan jati diri bangsa Indonesia.

Penelitian ini antara lain mencoba menelaah konsep Fikih Mazhab Indonesia menurut A. Qodri Azizy. Oleh karena itu, penelitian yang termasuk model pemikiran fuqaha ini, ditujukan untuk memahami berbagai unsur yang melekat pada pemikiran A. Qodri Azizy. Penelitian ini antara lain juga mencoba mengembangkan apresiasi terhadap pemikiran fuqaha sebagai wujud kebebasan berpikir dan berpendapat dalam entitas kehidupan muslim. Untuk selanjutnya muncul toleransi tinggi terhadap keragaman pandangan dan pemikiran. Sehingga, muncul iklim dialektis dalam bingkai demokratisasi keilmuan. Selain itu, juga dapat digunakan 
ljtihad, Jurnal Wacana Hukum Islam dan Kemanusiaan, Volume 15, No. 1, Juni 2015: 39-60

sebagai salah satu bahan rujukan dalam proses penataan kehidupan yang kian pelik dan majemuk dalam naungan pengembangan hukum nasional, sesuai konteks sosial budaya (Bisri, 2004).

Penelitian ini memilih fokus penelitian MPI (Model Pemikiran Internal), dengan penyempitan fokus penelitian berupa unsur kerangka pemikiran dan substansi pemikiran (Bisri, 2004: 196-197). Sesuai fokus penelitian MPI yang telah ditentukan, penelitian ini menggunakan jenis penelitian library research yang berkenaan dengan metode pengumpulan data pustaka, membaca dan mencatat, serta mengolah bahan penelitian (Zed, 2008: 3). Teknik pengumpulan data melalui dokumentasi. Sumber data primer dalam penelitian ini yakni karya A. Qodri Azizy, Reformasi Bermazhab: Sebuah Ikbtiar Menuju Ijtihad Saintifik-Modern (Jakarta: Teraju, 2003) dan Hukum Nasional: Elektisisme Hukum Islam dan Hukum Umum (Jakarta: Teraju, 2004). Sedangkan sumber sekunder melingkupi karya-karya pendukung dari pemikir lain yang relevan dan relasional dengan topik. Data dianalisis dengan melibatkan proses seleksi atau klasifikasi dalam upaya rekonstruksi teks dan konteks dalam wacana keseluruhan (Zed, 2008: 76).

Peneliti coba memahami dan mendeskripsikan keunikan pemikiran ijtihad A. Qodri Azizy yang memiliki kemampuan berpikir kreatif. Hal itu tampak dalam gagasan yang relatif orisinal yang diformulasikan dalam bentuk konsep dasar, epistemologi, dan paradigma fikih, ushul fikih, dan hukum Islam pada umumnya. Penelitian ini selanjutnya menelisik pemikiran ijtihad A. Qodri Azizy dalam konteks pembaruan hukum Islam Indonesia.

\section{Ijtihad pembaruan dan gagasan fikih Indonesia}

Ijtihad berawal dari kesadaran bahwa perkembangan diskursus fikih pernah mengalami masa-masa krisis kebekuan ijtihad dengan ketumpulan kreativitas akibat taqlid yang menghegemoni. Pada masa sejarah perkembangan fikih masa awal sampai terbentuknya mazhab terlihat jelas perbedaan hukum Islam di suatu wilayah dengan wilayah lain. Muncullah mazhab Madinah, mazhab Kufah, mazhab Basrah, dan lainnya yang tersohor, kemudian bertransformasi menjadi mazab Imam Maliki, Hanafi, Syafi'i, dan Hanbali yang oleh Josept Schacht disebut transformation of ancient schools into the personal schools dan Wael Hallaq dengan from regional personal schools of law. Namun, periode setelahnya mazhab-mazhab yang telah 
Reformulasi ijthad dalam pembaruan hukum Islam menuju hukum nasional: ... (Warkum Sumitro)

established dianggap telah cukup untuk menjadi referensi hukum Islam di wilayah manapun. Inilah yang menjadi awal munculnya karakter transnasional dalam fikih. Karakter ini kian menguat dengan masuknya kepentingan politik ideologis yang menyertai perkembangan mazhab fikih (Mawardi, 2010: 271).

Mazhab akhirnya bersifat doktrin dogmatis-apologis dan taqlid oriented. Namun di sisi lain, terdapat 'kaum-kaum kiri' yang menafikkan sense of the art warisan khazanah intelektual klasik karena dianggap out of the date dan menyerukan ijtihad yang sama sekali baru. 'Mazhab kiri' ini akhirnya bersifat liberal a bistoris-polemis dan unbistorical continuity oriented. Oleh karena itu perlu dilakukan dekonstruksi (konsep) ijtihad dan reformasi bermazhab yang mereposisi dan membuka jalan tengah dua kutub haluan pemikiran yang berseberangan tersebut (Azizy, 2003: 72).

Teori yang akan digunakan untuk memahami persoalan penelitian ini adalah teori pembaruan hukum Islam, dengan asumsi lahirnya pemikiran ijtihad A. Qodri Azizy adalah dalam kerangka mengurai stagnansi hukum Islam terhadap dinamika sosial budaya dengan berbagai konteks yang meliputi. Teori ini adalah teori menengah (messo) dari teori perubahan hukum (taghayyur al-abkēam) yang bersifat makro, berdasarkan kaidah taghayyur al-ạ̣käm bi taghyur al-amkinah wa al-azminah wa al-ahwäl, wa al-niyat wa al-'awaid. Dalam kaidah ini terdapat hubungan kausal antara hukum dengan waktu, tempat, keadaan, niat, dan kebiasaan. Hukum sebagai akibat, yang lainnya (konteks) sebagai sebab atau al-illah (Bisri, 2004: 196, 201). Teori ini digunakan dalam mengkaji ijtihad sebagai daya kreatif tinggi mujahid atau fakih yang berkelindan dengan tuntutan internal dan eksternal dari kemajemukan masyarakat muslim, dan interaksi dengan berbagai macam perangkat pranata sosial, tradisi dan teknologi. Selain itu, ijtihad juga mencirikan corak lokal dan tuntutan zaman saat mujtahid hidup, sehingga meniscayakan kontekstualisasi dengan berbasis pada kerangka referensi yang sudah mapan, sebagaimana kaidah al-muhäfazah 'alā al-qadim al-săalih wa al-akhd bi al-jadid al-așlah.

Fikih yang tumbuh dan berkembang di negara Timur Tengah tidak dengan serta merta dapat diterapkan di negara lain karena ada kemungkinan perbedaan kondisi, permasalahan, kebutuhan, kebiasaan, dan faktor lainnya yang membutuhan respon fikih kontemporer. Oleh karena kuatnya orientasi kemaslahatan dalam fikih kontemporer-yang menjadi titik utama tujuan hukum Islam (maqāsid al-shari'ah) dan dipengaruhi oleh pertimbangan tempat 
ljtihad, Jurnal Wacana Hukum Islam dan Kemanusiaan, Volume 15, No. 1, Juni 2015: 39-60

dan waktu—membuka lebar kemungkinan lahirnya ketentuan-ketentuan hukum Islam yang berbeda di suatu kawasan dengan kawasan lainnya, karena pertimbangan kemaslahatan. Oleh karena itu, dewasa ini muncul kecenderungan beralih dari fikih ideologis ke fikih geografis (Mawardi, 2010: 269-270).

Dalam konteks ini, fikih mazhab Indonesia menemui urgensinya yang lahir dari pergumulan pemikiran fikih dengan setting keindonesiaan dengan kompleksitas konteks yang melingkupi. Selain menjadi jalan tengah perdebatan 'mazhab kanan' yang menekankan pendekatan formal-tekstual dan 'mazhab kiri' yang menekankan pendekatan kultural-substansial.

Agus Moh. Najib (2011) melakukan studi pengembangan metodologis secara deskriptif kronologis fikih Indonesia yang dirunut para penggagasnya, dari awal tahun 1940-an sampai awal tahun 2000-an. Ia menelaah penggagas fikih Indonesia enam dekade tersebut (Shiddiqi, 1997). A. Qodri Azizy termasuk fokus kajian penelitiannya, di samping T.M. Hasbi Ash Shiddieqy, Hazairin, Munawir Sjadzali, Bustanul Arifin, dan Yusdian Wahyudi. Menurutnya, pemikiran fikih (mazhab) Indonesia berupaya melakukan kontekstualisasi hukum Islam dengan budaya dan realitas masyarakat Indonesia, setelah itu berupaya diformalkan untuk diberlakukan sebagai peraturan perundang-undangan, terutama peraturan perundangan nasional.

Konfigurasi tema-tema pemikiran hukum Islam (fikih) Indonesia juga dikaji panjang lebar oleh Mahsun Fuad dengan rentangan waktu 1970-2000 (Fuad, 2005). Ia mengulas lima tema pemikiran antara lain: (1) Fikih Indonesia T.M. Hasbi Ash Shiddieqy yang menggaungkan Fikih dengan kepribadian Indonesia; (2) Fikih Mazhab Nasional Hazairin yang mengupayakan penyatuan nilai-nilai adat dengan hukum Islam; (3) Reaktualisasi Ajaran (Doktrin) Islam Munawwir Sjadzali yang berupaya mereintepretasi doktrin Islam, (4) Agama Keadilan Masdar F. Mas'udi dengan penegakan kembali cita-cita sosial Islam; dan (5) Fikih Sosial MA. Sahal Mahfudh dan Ali Yafie yang menjadikan fikih sebagai etika sosial. Kelimanya (dan Bustanul Arifin) menunjukkan geneologi dan nasab pemikiran fikih (hukum Islam) 'mazhab' Indonesia yang secara langsung atau tidak sebagai frame of references ikut mempengaruhi pemikiran A. Qodri Azizy. Secara terstruktur kerangka konseptual Fiqh Indonesia dapat dilihat dalam Gambar 1. 


\section{Gambar 1:}

\section{Kerangka Konseptual Fikih Indonesia}

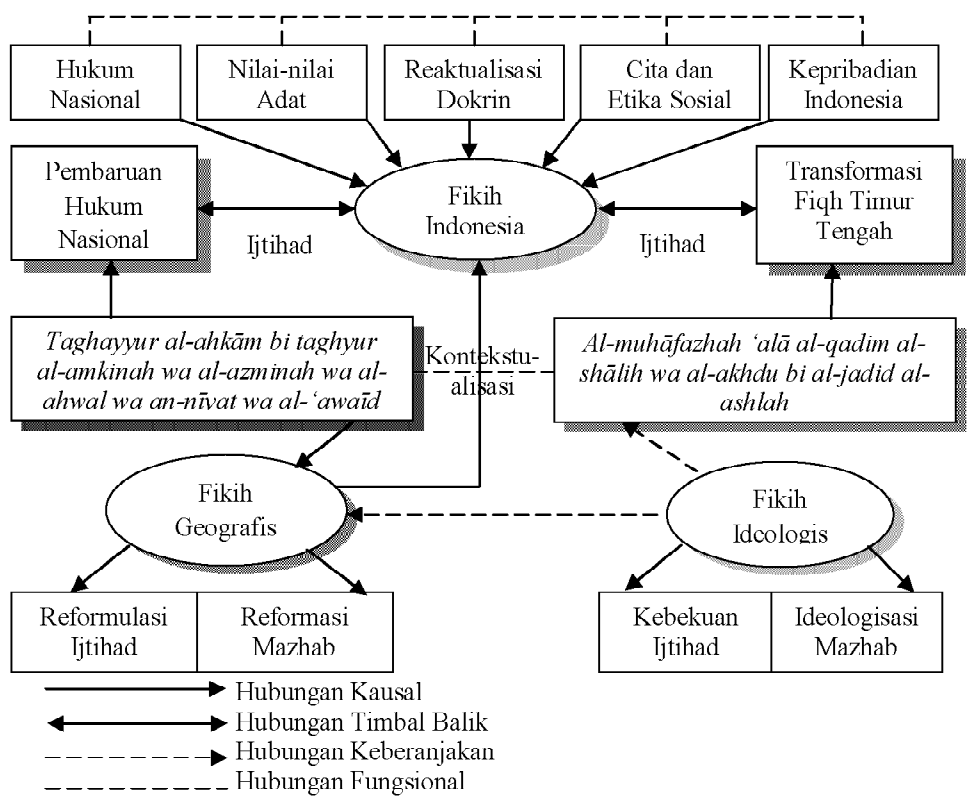

\section{Qodri Azizy dan pembaruan hukum Islam Indonesia}

Sebagai Guru Besar Hukum Islam di Fakultas Syari’ah IAIN Walisongo Semarang, dalam pengukuhannya, Qodri mempersembahkan salah satu master piece-nya, "Reformasi Bermazhab" yang memuat pemikiran ijtihad saintifik-modern tersebut. Akademisi yang sempat mengemban amanah Rektor IAIN Waalisongo periode 2001-2003_sebelum akhirnya mundur tahun 2002 karena dilantik menjadi Direktur Jenderal Kelembagaan Agama Islam Departemen Agama-berangkat dari kajian kritis terhadap konsep bermazhab, dengan mengupayakan level ke lima dalam pengembangan metodologi ijtihad. Selain itu ia juga pernah mengemban jabatan Sekertaris Menko Kesra yang menjadi medan aktualisasinya dalam menerapkan hukum Islam sebagai pandangan dunianya dalam menghadapi tantangan globalisasi dan pengembangan SDM bangsa.

Geliat bermazhab fi al-manhaj yang menjadi titik tolak al-ijtihād al-'ilm al-'assi (ijtihad saintifikmodern) Qodri banyak disorot dan dijadikan agenda utama rentang tahun 1989-1992. Baik 
ljtihad, Jurnal Wacana Hukum Islam dan Kemanusiaan, Volume 15, No. 1, Juni 2015: 39-60

dalam kolom-kolom media massa, maupun forum balaqab RMI dan mukhtamar NU (1989). Bahkan dalam keputusan Munas Alim Ulama NU di Bandar Lampung (1992), dalam sistem pengambilan keputusan, poin ke empat dari prosedur penjawaban disebutkan bila dalam kasus tidak ada qaul/wajah sama sekali tidak mungkin dapat dilakukan ilhaq (penyandaran/ analogi), maka bisa dilakukan istinbat jama'i dengan prosedur bermazhab secara manbaji (metode) oleh para ahlinya (Azizy, 2003: 62-63). Menurut Ahmad Rofiq (2001: 172), hal tersebut menunjukkan pembaruan formulasi Hukum Islam di tubuh NU. Lembaga tajdid dan ijtihad dianggap perlu untuk menjawab persoalan hukum modern dengan menggunakan metode-metode rumusan ulama seperti qiyas, istibsan, maslahat mursalah, dan sadd al-zari'ah.

Kreativitas dan pembaruan dalam pengambilan hukum Islam menjadi agenda penting umat Islam dalam mengisi reformasi hukum Indonesia. Era ini ditandai dengan arah dan kebijakan hukum nasional yang sekaligus politik hukum nasional harus berlandaskan GarisGaris Besar Haluan Negara (GBHN) tahun 1999. Dalam hal ini hukum Islam disandingkan dengan hukum Adat dan hukum Barat sebagai bahan baku hukum Nasional. Selanjutnya di tengah persaingan ketiganya, agar dapat kian diberlakukan hukum Islam dituntut untuk mampu menyumbangkan nilai-nilainya dalam rangka kemajuan, keteraturan, ketentraman dan kesejahteraan berbangsa dan bernegara.

Dalam sejarah konfigurasi pemikiran pemberlakuan hukum Islam, muncul teori Receptio in Complexu oleh van den Berg (1845-1868) pada masa kolonial yang menyatakan hukum Islam yang menjadi basis keberagamaan penduduk yang pada saat itu diperkenankan terus dijalankan seperti sebelumnya. Namun, karena lambat laun kebijakan tersebut dianggap memperkuat basis gerakan umat Islam terhadap kolonial, diusunglah upaya untuk memisahkan umat Islam dari bidang hukum Islam. Dirumuskanlah teori receptie oleh Christian Snouck Hurgronye (1857-1936) yang mengatakan, bagi rakyat pribumi pada dasarnya berlaku hukum adat dan hukum Islam berlaku apabila normanya itu telah diterima oleh masyarakat sebagai hukum adat. Teori receptie yang dikembangkan oleh Hurgronye mendapat tantangan hingga memasuki kemerdekaan. Salah satu penentang lantang adalah Hazairin (1950), yang berpendirian bahwa setelah Indonesia memproklamirkan kemerdekaan, maka seluruh peraturan perundang-undangan pemerintah Hindia Belanda yang mendasarkan pada teori Receptie dianggap tidak berlaku lagi karena jiwaya bertentangan dengan UUD 1945 
Reformulasi ijthad dalam pembaruan hukum Islam menuju hukum nasional: ... (Warkum Sumitro)

(pasal II Aturan Peralihan). Teori Receptie harus exit karena bertentangan dengan al-Qur'an dan Sunnah yang membuka potensi lebar umat Islam tidak menjalankan syariat Islam. Ia menyebut teori Receptie sebagai “teori iblis". Kemudian muncul teori receptio a contrario Sayuti Thalib dan teori eksistensi oleh Ichtijanto yang bernada sama, bahwa hukum Islam eksis sebagai salah satu sumber hukum nasional (Rosyadi dan Ahmad, 2006: 78-79).

Semangat untuk memberangus teori reseptie, dibawa Qodri Azizy dalam kajian historiknya. Hal ini terkait pembahasan wewenang Pengadilan Agama yang dimarginalisasikan oleh teori reseptie menjadi Peradilan "Pupuk Bawang" yang martabatnya seolah-olah dibuat di bawah peradilan Negeri. Peradilan Agama yang mengaplikasikan hukum Islam atas politik pemerintahan kolonial dibuat hanya terbatas pada masalah nikah, talaq, cerai, dan rujuk (NTCR) saja. Hakim Peradilan Agama juga mengalami diskriminasi dibanding hakim Pengadilan Negeri dalam hal gaji dan hak-hak keprofesiannya.

Tabel 1:

Konteks Pemikiran A. Qodri Azizy

\begin{tabular}{|c|c|c|c|}
\hline Ketokohan (Struktur) & Kerangka Pemikiran & $\begin{array}{c}\text { Entitas Kehidupan } \\
\text { (Kultur) }\end{array}$ & $\begin{array}{c}\text { Instrumen } \\
\text { Perubahan Sosial }\end{array}$ \\
\hline $\begin{array}{l}\text { 1. Guru Besar I Tukum } \\
\text { Islam } \\
\text { 2. Rcktor IAIN } \\
\text { Walisongo } \\
\text { 3. Direktur Jenderal } \\
\text { Kolsmbagaan } \\
\text { Agama Islam } \\
\text { Inspektural Jerideral } \\
\text { Departemen Agama } \\
\text { 4. Sekertaris Menko } \\
\text { Kcsra }\end{array}$ & $\begin{array}{l}\text { Pembaruan T Tukum } \\
\text { Islam: } \\
\text { 1. Redefinisi dan } \\
\text { Tingkatan } \\
\text { Bermazhab } \\
\text { 2. Ijtihad Saintifik- } \\
\text { Modem } \\
\text { 3. Eklektisisme I Iukum } \\
\text { Nasional } \\
\text { 4. Positivisasi Hukum } \\
\text { Islam }\end{array}$ & $\begin{array}{l}\text { 1. Pluralitas Sistem } \\
\text { Hukum Indonesia } \\
\text { (Hukum Adat, } \\
\text { I Iukum Agama, } \\
\text { Hukum Belarıda) } \\
\text { 2. Pcmbangunan } \\
\text { Hukum Nasional }\end{array}$ & $\begin{array}{l}\text { 1. Muktamar NU dan } \\
\text { Munas Alim Ulama } \\
\text { NU: Benmazhal, fi } \\
\text { al-manhaj } \\
\text { 2. GBHN } 1999 \\
\text { 3. Kowcnangan } \\
\text { Peradilan Agama } \\
\text { dan One Roof Sistem }\end{array}$ \\
\hline
\end{tabular}

Pembaruan transformasi Peradilan Agama sudah dimulai sejak ditetapkan UU No. 14 Tahun 1970. Namun, independensinya masih dipersoalkan, karena masih menganut sistem dua atap (double roof system), seperti termaktub pada Pasal 11 Ayat (1). Setelah diundangkan UU No. 7 Tahun 1989, akhirnya Peradilan Agama dialihkan ke dalam lingkungan Mahkamah Agung dengan sistem satu atap (one roof system). Akan tetapi, kewenangan yang disandang Peradilan Agama kala itu masih sangat terbatas. Penyelesaian sengketa yang menjadi 
ljtihad, Jurnal Wacana Hukum Islam dan Kemanusiaan, Volume 15, No. 1, Juni 2015: 39-60

kompetensi absolut Peradilan Agama masih berkisar penyelesaian masalah NTCR saja (Sumitro, dkk, 2014: 141).

Kewenangan absolut Peradilan Agama mengalami transformasi signifikan secara konstitusional melalui Undang-Undang No. 3 Tahun 2006 tentang Perubahan Atas UndangUndang No. 7 Tahun 1989 tentang Peradilan Agama. Undang-Undang ini dilatarbelakangi munculnya UU No. 4 tahun 2004 tentang Kekuasaan Kehakiman sebagai Undang-Undang organik atas pasal 24 UUD tahun 1945. Ada dua puluh dua macam kewenangan yang diatur dalam penjelasan Pasal 49 UU No. 3 Tahun 2006. Di antaranya adalah perkawinan, waris, wasiat, hibah, wakaf, shadaqah, infak, zakat, penetapan pengangkatan anak (adopsi), penetapan hasil hisab dan rukyat, serta ekonomi syari’ah yang mengandung kewenangan mengadili sebelas macam persoalan baru. Dalam perjalanan transformatifnya, bertambah luasnya kompetensi absolut Peradilan Agama diiringi dengan berbagai upaya penyesuaian. Pada tanggal 29 Oktober 2009, disahkanlah UU No. 50 tahun 2009 tentang perubahan kedua atas UU No. 7 tahun 1989 tentang Peradilan Agama (Sumitro, dkk, 2014: 142).

Lebih luas lagi, selain undang-undang Peradilan Agama, kerangka pemikiran yang berkembang dalam peraturan dan perundang-undangan nasional didasarkan pada kenyataan hukum Islam yang berjalan di masyarakat. Pengamalan dan pelaksanaan hukum Islam yang berkenan dengan puasa, zakat, haji, infak, sedekah, hibah, baitul-mal, hari-hari raya besar Islam, selalu ditatai masyarakat dan bangsa Indonesia. Melihat adanya hubungan yang sangat sinergis antara hukum Islam dan hukum nasional, maka dapat menjadi suatu indikator bahwa hukum Islam telah eksis dan semestinya diakomodasi sebagai sumber hukum nasional (Rosyadi dan Ahmad, 2006: 89).

\section{Reformasi bermazhab dan ikhtiar metodologis fikih Indonesia}

Entitas kehidupan bangsa Indonesia yang menunjukkan kemajemukan dan keragaman elemen-elemen bangsa meniscayakan asimilasi hukum Islam dengan sosial budaya masyarakat. Apalagi sejarah Indonesia menunjukkan eksistensi hukum Barat (Belanda) dan hukum Adat (kebiasaan) yang mengakar dalam stuktur dan kultur masyarakat sebagai warisan kolonial dan nenek moyang. Oleh karena itu, perkembangan hukum nasional akan mencakup tiga elemen sumber hukum tersebut dalam kedudukan sama dan seimbang. Namun, realisasinya 
Reformulasi iithad dalam pembaruan hukum Islam menuju hukum nasional: ... (Warkum Sumitro)

tetap dituntut agar demokratis yang mencerminkan kompetisi bebas dan kemungkinan terjadinya eklektisisme, bukan pemaksaan dari rezim untuk menerapkan salah satunya. Oleh karena itu, diperlukan sistem kerja positivisasi hukum Islam yang dapat diterima secara keilmuan dan dalam proses demokratisasi, bukan indoktrinasi. Positivisasi ini melalui proses keilmuan dalam disiplin ilmu hukum (jurisprudence) dan sistem politik yang demokratis (Azizy, 2003: 208-209).

Namun, sering kali muncul persoalan kira-kira hukum Islam yang mana yang digunakan ketika membingcang dalam konteks kenegaraan dan kebangsaan. Apalagi dengan pluralitas dan heterogenitas pandangan keislaman dan kondisi kemasyarakatan. Oleh karena itu, fikih (mazhab) Indonesia dapat menjadi jalan solutif. Dalam hal ini A. Qodri Azizy menyadari dan cukup artikulatif mengenai diskursus fikih (mazhab) Indonesia dalam tulisannya:

Perbedaan pendapat dan juga perbedaan mazhab tersebut (Maliki, Hanafi, Syafi'i, dan Hambali-pen) ada pengaruh faktor budaya kedaerahan atau yang biasa disebut 'urf atau 'adah (adat kebiasaan), meskipun pengaruhnya itu tidak semata-mata kepada esensi hukumnya. Namun lebih berpengaruh terhadap mujtahid/faqih yang kemudian berdampak pada hasil pemikiranr atau ijtihadnya. Oleh karena itu, di Indonesia juga muncul pendapat untuk menciptakan "mazhab ala Indonesia". Atau setidaknya agar berusaha menemukan hukum Islam yang sesuai sosio-kultural bangsa Indonesia, yang dalam banyak hal terdapat masyarakat di negara-negara Arab. Bahkan yang terjadi bukan saja untuk mewujudkan mazhab Indonesia, namun sekaligus pemikiran Hukum Islam secara mendasar yang sesuai dengan sosio-kultural bangsa Indonesia (Azizy, 2003: 1920).

Dalam upaya menyesuaikan fiqh dengan latar keindonesiaan, Qodri meredefinisi konsep bermazhab. Pasalnya, yang maklum dipahami dengan bermazhab adalah identik dengan ber-taqlid. Padahal, taqlid adalah bentuk bermazhab yang paling rendah, yakni urutan pertama dari lima tingkatan yang masih bisa disebut bermazhab. Urutan inilah antara lain yang menjadi agenda reformasi bermazhab Qodri dalam meretas stagnasi dalam hukum Islam. Dari telaah Qodri, bermazhab dapat dikelompokkan menjadi beberapa level (Azizy, 2003: 1920): Pertama, taqlid kepada ulama Syafi'iyyah. Ungkapan atau anggapan taqlid kepada imam Syafi'i yang umum dipahami, sebagian besar hakikatnya adalah ber-taqlid kepada fukaha Syafi'iyyah (ulama yang bermazhab Syafi'i) yang thabaqat-nya (tingkatan keilmuan dan masa hidupnya) jauh dari imam Syafi'i itu sendiri. Telaah Qodri berdasarkan realitas sistem 
ljtihad, Jurnal Wacana Hukum Islam dan Kemanusiaan, Volume 15, No. 1, Juni 2015: 39-60

pengambilan hukum kebanyakan ulama dan beberapa lembaga atau organisasi, yang justru kitab-kitab karya imam Syafi'i sendiri tidak dijadikan sumber sekunder, apalagi sumber primer. Kedua, taqlid kepada imam Syafi'i secara langsung. Level ini selalu merujuk kitabkitab yang ditulis sendiri imam Syafi'i, yang realitasnya tidak begitu populer di masyarakat dan hanya dimiliki ulama yang jumlahnya sangat terbatas.

Pendapat Qodri tentang bermazab fi al-Aqwall (mengikuti mazhab dari pendapat yang sudah matang, tanpa mempelajari metodologi/manbaj-nya) memang krusial dan hingga kini masih banyak ditemukan dalam masyarakat, di lembaga pendidikan atau organisasi kemasyarakatan. Bahkan referensi perumusan Kompilasi Hukum Islam (KHI) yang merupakan produk pembaruan hukum Islam Indonesia dan dijadikan landasan hukum utama hakim Peradilan Agama juga juga tidak langsung pada kitab-kitab imam Syafi'i. Namun, demikian tidak serta merta dapat dipahami merupakan gambaran historis yang jauh dari khitah pemikiran imam Syafi'i. Justru hal ini merupakan keberlanjutan khazanah pemikiran hukum Islam seperti yang disebut Qodri sendiri dengan bistorical continuity. Namun, yang dikhawatirkan adalah ideologisasi mazhab Syafi'iyyah dengan bias status quo kejumawaan mazhab. Apalagi sikap a priori terhadap kemungkinan interpretasi baru dan masuknya aspirasi mazhab lain dengan kajian lintas mazhab.

Ketiga, Ittiba' pada ulama Syafi'iyyah, atau langsung kepada imam Syafi'i. Level ini mengikuti imam Syaf'i dengan menjadikan karya-karyanya sebagai rujukan sekaligus mengetahui alasan dan dalil, serta proses beragumentasi imam Syafi'i. Level ini memungkinkan adanya tarjih (penilaian dengan mengambil yang dianggap lebih kuat) secara internal dalam mazhab tertentu. Keempat, bermazhab fi al-manhaj. Level ini sudah memratikkan ijtihad, masih sangat terbatas dengan manhaj (metode) yang dipakai imam Syafi'i, belum mampu mengembangkan. Ijtihad dalam bermazhab fi al-manhaj bukan hanya dalam kasus-kasus baru yang belum terdapat pendapat ulama. Namun memungkinkan re-examine (menguji/menilai ulang) terhadap pendapat ulama yang dianggap sudah tidak sesuai sesuai kondisi yang ada dengan tetap berpegang dengan manhaj imamnya. Oleh karenanya, level ini memungkinkan perbedaan keputusan hukum dengan imam mazhabnya dan bahkan merevisinya. Dalam level ini, kaidah taghayyur al-ahkeām bi taghyur al-amkinah wa al-azminah wa al-aḥwäl, wa al-nìyat wa al-'awäid memenuhi taraf implementasinya. Kelima, mengembangkan metodologi. Level ini banyak 
Reformulasi ijthad dalam pembaruan hukum Islam menuju hukum nasional: ... (Warkum Sumitro)

ditempuh ulama pengikut mazhab Syafi'i yang mendapatkan predikat mujaddid (pembaru) dalam hukum Islam. Dalam tataran tertentu tidak hanya mengembangkan, bahkan menciptakan manbaj baru yang diakui secara akademik dan berkesinambungan dengan prosedur dan hasil masa lalu (bistorical continuity).

Level dalam bermazhab ini menunjukkan anomali perubahan sosial dalam pemikiran hukum Islam. Rentangan masa stagnansi dan kemunduran uamat Islam antara lain menunjukkan tradisi bermazhab fi al-aqwäl yang mendominasi dan mengakar. Bahkan pernah ada isu tertutupya pintu ijtihad karena dilandasi pemikiran akan superioritas dan sakralitas imam mazhab yang notabene berada dalam tataran fikih (bukan syari'ah). Oleh karenanya, bermazhab fi al-manhaj menjadi keniscayaan, apa lagi dalam konteks hukum nasional yang membuka gelanggang lebar persaingan hukum Islam dengan hukum Barat dan hukum Adat dalam bingkai demokratisasi dan justifikasi akademik sesuai kondisi keindonesiaan. Sketsa reformasi bermazhab dan positivisasi hukum Islam dapat dilihat pada Gambar 3.

\section{Gambar 2:}

\section{Skema Reformasi Bermazhab dan Positivisasi Hukum Islam (Fikih)}

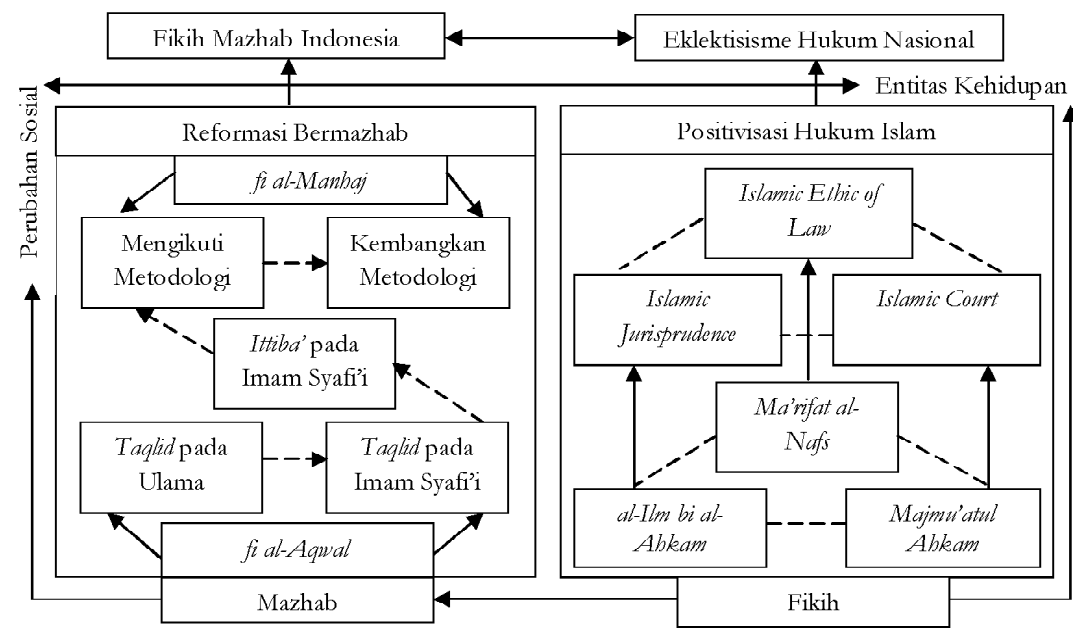

Bermazhab fi al-aqwall mendominasi milenium terakhir perkembangan hukum Islam di Asia Tenggara yang diakari mazhab Syafi'iyyah. Di Asia Tenggara tersebar mazhab Syafi'i melalui sosialisasi yang masif dan homogen dari tokoh-tokoh ulama, lembaga pengajaran, 
ljtihad, Jurnal Wacana Hukum Islam dan Kemanusiaan, Volume 15, No. 1, Juni 2015: 39-60

dan sumber kitab rujukan yang bermazhab Syafi'i yang secara praksis diterapkan dalam amaliyah beribadah dan bermuamalah masyarakat. Pun disokong kekuasaan yang mengakomodasi aspirasi madzab Syafi'i dengan politik hukum, kodifikasi hukum Islam, dan peradilan (Syarifuddin, 2002: 108-119). Namun, karena sudah begitu terinstusionalisasi, fenomena bermazhab (Syafi'iyyah) diwarnai dengan menerima produk pemikiran fikih yang berlatar timur tengah taken for granted an sich, tanpa mengkaji landasan metodologis untuk selanjutnya dikembangkan. Hal ini disadari A. Qodri Azizy sebagai berikut:

.... sedangkan di Indonesia dan Malaysia yang dominan adalah mazhab Syafi'i. Perlu kita ketahui bahwa dalam masa berabad-abad, mazhab itu mendominasi perkembangan hukum Islam dan pemikirannya. Bahkan, tidak jarang pemikiran hukum Islam di masingmasing mazhab itu dipahami secara doktrinal dan dogmatik.... Inilah yang kemudian disebut dengan mazhab fi al-aqwal (Azizy, 2003: 10).

Padahal, dalam geneologi historis tentang generasi awal mazhab menunjukkan betapa faktorfaktor lokal dan regional menjadi pertimbangan serius. Joseph Schacht sebagaimana dikutip Qodri (2003: 28) menulis bahwa mazhab-mazhab hukum klasik menerima doktrin-doktrin yang bersifat kedaerahan sebagai hal wajar dan mereka menyuarakan keberatan mendalam terhadap perselisihan mazhab. Dua hal pokok yang menjadi elan vital perbedaan mazhab hukum klasik yakni: (1) elemen lokal yang sangat kuat yang menunjukkan bahwa hukum Islam fleksibel pada saat itu; dan (2) praktik atau ulah pendapat personal dari tiap-tiap ulama, sebagai wujud kebebasan berpendapat dalam pemikiran hukum (Azizy, 2003: 34).

Semangat ini yang antara lain melatarbelakangi menyeruaknya geliat intelektual rentang tahun 1970-2000 yang menawarkan rancang bangun konsep dan metode fikih ala Indonesa atau fikih yang mempunyai spirit khas keindonesiaan. Geneologi dan nasab pemikiran fikih (hukum Islam) 'mazhab' Indonesia ini secara langsung atau tidak menjadi kerangka acuan (frame of references) konstruksi pemikiran A. Qodri Azizy yang dalam banyak segi memiliki kesenadaan dengan haluan pemikirannya. Bidikan Qodri dalam hal hukum Islam dan hukum nasional, fikih sebagai etika agama, sumber dan prosedur praktik peradilan juga diusung para penggagas fikih (mazhab) Indonesia sebelumnya.

T.M. Hasbi Ash Shiddieqy terhitung menjadi penggagas awal yang mengusung fikih yang ditetapkan sesuai kepribadian Indonesia, yaitu sesuai dengan tabiat dan watak lokal 
Reformulasi ijtihad dalam pembaruan hukum Islam menuju hukum nasional: ... (Warkum Sumitro)

masyarakat Indonesia. Keberadaan adat Indonesia menjadi nilai yang harus dianeksasikan ke dalam hukum Islam, sehingga cocok untuk masyarakat Indonesia. Sementara itu, Hazairin mengupayakan penyatuan nilai-nilai adat dengan hukum Islam melalui penyelarasan nilainilai adat dengan hukum Islam, sehingga cocok dan pas diterapkan di Indonesia. Demikian pula, Munawwir Sjadzali, yang berupaya mengontekstualisasikan ajaran melalui reintepretasi doktrin ajaran Islam. Dengan upaya ini, hukum Islam akan relevan dengan perubahan, sehingga perilaku mendua (talfiq) dapat dihindari. Dalam upaya memperlebar peran dan pengaruh hukum Islam, Bustanul Arifin mengupayakan pelembagaan hukum Islam, meski lebih menampilkan birokrasi sebagai lokomotif pembaruan pemikiran hukum Islam di Indonesia. Demikian berpengaruh pula, Masdar F. Mas'udi, dengan penegakan kembali cita-cita sosial Islam melalui upaya pengembalian elemen dasar nilai kemaslahatan, keadilan sosial dan hak asasi manusia (egaliterianisme) di dalam bangunan pemikiran hukum Islam (fikih). Fikih Sosial MA. Sahal Mahfuth dan Ali Yafie memperlengkap khazanah ini dengan berupaya mengaktualisasi fikih mazhab (tradisional) melalui upaya aktualisasi nilai-nilai yang ada di dalamnya untuk dioptimalkan pelaksanaan dan diserasikan dengan tuntutan makna sosial yang terus berkembang. Tujuannya, membentuk suatu konsep fikih yang berdimensi sosial atau fikih yang dibangun berkaitan dengan sejumlah peranan individu atau kelompok dalam masyarakat (Fuad, 2005: 236-238).

\section{Reformulasi ijtihad menuju hukum nasional}

A. Qodri Azizy dalam kajian tentang hukum Islam selalu menegaskan dan meredefinisi fikih yang sering dinggap terkait ilmu hukum an sich. Fikih dalam lingkup hukum memang biasa didefinisikan dengan al-ilm bi al-abkām al-syar'iyyah al-'amaliyah al-muktasabah min adillatiha altafșiliyyah (ilmu mengenai hukum-hukum syar'i yang [berkaitan dengan] perbuatan/tindakan [bukan aqidah] yang didapatkan dari dalil-dalil yang spesifik). Fikih juga didefinisikan dengan majmuat al-abkām (kumpulan hukum) al-shyar'iyyah al-'amaliyyah al-mustafadah min adillatiha altafșiliyyah (Khallaf, 1978: 11). Definisi ini menunjukkan fikih sebagai ilmu hukum Islam (Islamic Jurisprudence) dan berupa materi hukum bahkan juga prosedur dalam proses peradilan (hukum acara, fikih murafa'at, Islamic court). 
ljtihad, Jurnal Wacana Hukum Islam dan Kemanusiaan, Volume 15, No. 1, Juni 2015: 39-60

Namun, dari telaah Qodri, lingkup pembahasan fikih tidak selalu diartikan 'hukum Islam' dan identik dengan law/rules atau peraturan perundang-undangan, sehingga disebut 'hukum positif Islam'. Apalagi bila dalam konteks Indonesia, pembahasan hukum Islam dianggap terbatas pada wewenang atau kelembagaan Peradilan Agama an sich. Selain mempersempit diskursus dan implementasi hukum Islam, juga akan menimbulkan bias polarisasi dikotomi hukum Islam dan hukum umum yang diposisikan menjadi dua kutub yang sama sekali bertentangan, yang menurut Qodri sama saja dengan sekularisme (bukan sekularisasi). Menurutnya, dengan demikian sebenarnya sedang berlangsung praktik proses sekularisme hukum, selain hukum keluarga. Padahal masih banyak yang seharusnya dipasok atau dimasuki oleh hukum Islam sebagai salah satu bahan baku hukum nasional: dari materi hukum, etika penegak hukum, maupun etika kelembagaan itu sendiri (Azizy, 2003: 198).

Seperti halnya dalam konsep fikih dikenal al-Ahkam al-Khamsah, lima hukum Islam (halal, haram, sunah, makruh, dan mubah) yang memiliki kandungan nilai ibadah yang sarat dengan pahala (tsawab) dan siksaan/hukuman (iqab) dan berkonsentrasi akhirat. Pembahasan fikih sebagai etika hukum sesuai dengan definisi fikih yang diungkapkan Abu Hanifah, yakni ma'rifat al-nafs mà lahà wa mà 'alayhà 'amalan (mengetahui hak dan kewajiban yang berkaitan dengan perilaku seseorang). Konsep hak dan kewajiban adalah konsep etika yang bila dilanggar akan memberikan keburukan dan kerusakan kepada individu maupun masyarakat. Selain itu, aktualisasi budaya hukum (legal culture) yang melingkupi profesionalisme penegakan hukum (law enforcemen) dan ketaatan hukum masyarakat yang baik akan lebih bisa diimplementasikan, karena disertai etika agama (religious etbic [Islam]) tentang hukum (Islamic ethic of law) yang memiliki dimensi ukhrawi (Azizy, 2003: 14-15).

Dalam pembahasan hukum Islam sebagai etika hukum, nampak Qodri bukan hanya sesederhana mengisyaratkan masalah kesopanan semata. Melainkan etika dimaksudkan dalam pengertian yang lebih mendasar, seperti telaah Nurcholish Madjid (1995: 466), sebagai konsep dan ajaran yang seluas-luasnya (komprehensif) yang menjadi pangkal pandangan hidup tentang baik dan buruk, benar dan salah. Mencakup keseluruhan pandangan dunia (weltanschannng, world outlook) dan pandangan hidup (liebenanschanung, way of live). Etika (dari ethos) adalah sebanding dengan moral (dari mos) yang merupakan filsafat tentang adat kebiasaan (Sitten). Secara umum, etika adalah filsafat, ilmu, atau disiplin tentang moda-moda (mode) atau 
Reformulasi iithad dalam pembaruan hukum Islam menuju hukum nasional: ... (Warkum Sumitro)

konstansi-konstansi (constancy, ketegasan atau kepatuhan) tingah laku manusia. Hal ini begitu penting, sebab hukum tanpa etika, menurut Qodri, sama artinya bukan hukum atau sama artinya dengan kezaliman yang menyeruak dengan wujud kolusi, korupsi, dan nepotisme akut. Fikih sebagai etika hukum transenden yang memilki kesadaran hukum tidak hanya mempunyai konsekuensi administratif di dunia, tapi juga konsekuensi pahala dan dosa di akhirat kelak.

Hukum Islam sebagai doktrin nomatif-etik tidak lepas dari konteks tempo dan lokus keberlakuannya. Daerah Arabia yang menjadi wilayah awal kemunculan Islam dengan berbagai konteks sosio-kulturalnya ikut memengaruhi desain hukum dan paradigmanya. Namun, penyebarluasan Islam dengan berbagai ajarannya meniscayaakan asimilasi terhadap kondisi objek dakwah. Dalam ranah mikro maupun makro tentu sudah ada tatanan sedemikian rupa sebagai local genius peradaban tertentu. Dalam konteks Asia Tenggara, peradaban Timur yang dibopong Islam mampu ramah menyapa aset-aset kultur pribumi dan berintegrasi menjadi local genius baru. Islam mampu bergumul dan berdialektika dengan berbagai doktrin lokal sesuai kebutuhan dan naluri masyarakat.

Dalam telaah An-Naim, Islam keindo-nesiaan merupakan Islam yang mempunyai ciri dan karakteristik unik dengan heterogenitas penduduknya. Sehingga dalam proses legislasinya para elit partai yang berbasis Islam harus benar-benar mengakomodir karakteristik hukum Islam, dengan mereformulasikan legislasi hukum Islam ala keindonesiaan (An-Na'im, 2002: 99). Bahkan Imam Syaukani penah melontarkan ungkapan radikal bahwa hukum Islam yang ada di Indonesia merupakan produk impor. Tidak berlebihan apabila hukum Islam yang terkonfigurasi dalam fikih dianggap barang antik yang hanya layak dimuseumkan (Syaukani, 2006: 44).

Dengan begitu, masalah pembaruan hukum Islam dengan upaya meredefinisikan dalam kon-teks keindonesian adalah sebuah kebutuhan yang harus dipenuhi (Syaukani, 2006: 34-35). Apabila mayoritas masyarakat muslim menginginkan ajaran Islam senantiasa sesuai dengan perkembangan masyarakat dan memberikan jawaban positif terhadap berbagai permasalahan umat yang menuntut penyelesaian segera. Ini sangat rasional dan tidak menyalahi ajaran Islam itu sendiri. Hal ini memunculkan adagium di kalangan ahli hukum Islam yang diadopsi dari ungkapan al-Syahrastani (w. 548 H/1153 M), yaitu, “Teks-teks nash itu terbatas sedangkan 
ljtihad, Jurnal Wacana Hukum Islam dan Kemanusiaan, Volume 15, No. 1, Juni 2015: 39-60

problematika hukum yang memerlukan solusi itu tidak terbatas. Oleh karena itu, diperlukan ijtihad untuk menginterpretasi nash yang terbatas itu agar berbagai masalah yang tidak dikemukakan secara eksplisit dalam nash dapat dicari pemecahannya". Oleh karena itu, kaidah al-muhạfaz̧ah 'alā al-qadìm al-ṣâliḥ wa al-akhdh bi al-jadid al-aṣlạ̣ menjadi keharusan dalam meneruskan dan melengkapi keberlanjutan khazanah pemikiran hukum Islam.

Menurut An-Na'im, sebagaimana diungkapkan Muhyar Fanani, pola ideal dalam proses formalisasi hukum Islam ke dalam hukum nasional adalah dengan pola nasionalisasi hukum Islam, bukan berangkat dari pola Islamisasi hukum nasional yang cenderung ortodoks. Menurut An-Na'im bahwa kehadiran pola nasionalisasi hukum Islam merupakan agenda menyinergikan hukum Islam dengan hukum nasional secara transformatif-kontekstual. Pola ini yang tidak mengedepankan simbol-simbol syariah Islam dalam produk perundangundangannya. Akan tetapi penekananya lebih pada aspek substansinya yang diadopsi dari hukum Islam namun menggunakan simbol nasional (Fanani, 2008: 91).

Sementara pola yang ke dua menurut, An-Na'im adalah pola Islamisasi hukum nasional yaitu sebuah upaya memasukkan hukum Islam secara normatif ke dalam hukum nasional. Upaya tersebut acap kali lebih mengedepankan simbol-simbol keislaman yang eksklusif dan mengabaikan pluralitas masyarakat Indonesia yang heterogen. Konsekuensi dari pola ini akan melahirkan Islam simbolis yang tidak ramah lingkungan dalam konteks keindonesiaan (Fanani, 2008: 91).

Untuk mewujudkan ijtihad modern yang mampu merespon problematika masa kini dan masa datang, diperlukan langkah membangun formulasi baru. Ijtihad ini dapat menjembatani kalangan fundamentalis yang memaksakan formalisasi syariat Islam dan kalangan substansialis yang menampakkan corak apologis dalam menginternalisasikam prinsip hukum Islam. Dibutuhkan ijtihad yang satu sisi memang benar-benar melalui proses istinbath hukum. Di sisi yang lain tidak abai dalam menyapa realitas sosial keindonesiaan.

A. Qodri Azizy menawarkan model ijtihad yang diberi nama al-ijtihäd al-ím al-'așì atau modern scientific ijtihad (ijtihad saintifik-modern). Ijtihad ini dapat dilakukan dengan tematik (maudlu ) atau kasus per kasus, bukan serta merta menjadi manusia super seperti pendiri mazhab dengan melakukan ijtihad semua aspek kehidupan umat (Azizy, 2003: 110-126). Menurut Qodri, abad belakangan memang sering dipertanyakan hukum Islam yang benar-benar dapat membangun 
Reformulasi iithad dalam pembaruan hukum Islam menuju hukum nasional: ... (Warkum Sumitro)

masyarakat yang modern, kaya (prosperous), adil, makmur, aman dalam kehidupan yang plural di tengah era globalisasi. Tantangan baru hukum Islam ini meniscayakan formulasi ijtihad baru yang tidak lepas proses continuity dari bermazhab dan ijtihad masa lalu.

Ijtihad saintifik-modern ini ditempuh dengan sebelas hal, yakni (Azizy, 2003: 110-125): (1) lebih mementingkan atau mendahulukan sumber primer (primary sources) dalam sistem bermazhab atau menentukan rujukan. Seperti halnya merujuk langsung ke kitab imam Syafi'i menjadi penting dalam upaya verifikasi fakta (fact) dan bukti (evidence), serta memperoleh kebenaran sejarah (bistorical truth), apalagi ulama belakangan selalu melegitimasi dan menjustifikasi pendapatnya pada imam Syafi'i; (2) berani mengkaji pemikiran ulama atau hasil keputusan hukum Islam oleh organisasi keagamaan tidak lagi secara doktriner dan dogmatis, namun dengan critical study sebagai sejarah pemikiran (bistory of ideas); (3) semua hasil karya ulama masa lalu diposisikan sebagai pengetahuan (knowledge), baik yang dihasilkan atas dasar deduktif dan verstehen maupun secara empirik, sehingga bisa diuji ulang (re-examine); (4) mempunyai sikap terbuka terhadap dunia luar dan bersedia mengantisipasi hal-hal yang akan terjadi, bukan sekedar asal tidak setuju (aprior); (5) meningkatkan daya tanggap (responsif) dan cepat terhadap permasalahan yang muncul; (6) penafsiran yang aktif dan progesif yang mampu memberikan inspirasi kehidupan umat dan proyektif terhadap masa depan; (7) ajaran al-abkeam dapat dijadikan sebagai konsep atau etika sosial; (8) menjadikan ilmu fikih sebagai bagian ilmu hukum secara umum; (9) keseimbangan orientasi kajian induktif atau empirik fikih, di samping kajian deduktif dari nash; (10) masăalị̆ 'ammah menjadi landasan penting mewujudkan fikih/hukum Islam; dan (11) menjadikan nash sebagai kontrol etik hasil ijtihad.

Sejarah perkembangan hukum Islam di Indonesia sendiri pasca kemerdekaan telah mencatat bahwa legislasi hukum Islam secara konfiguratif dimulai sejak lahirnya UU No. 1 Tahun 1974 tentang Perkawinan hingga lahirnya UU No. 21 Tahun 2008 tentang Perbankan Syariah. Rentan waktu selama 34 tahun dari tahun 1974 hingga 2008 dengan 18 produk hukum Islam tersebut merupakan sebuah keberhasilan dalam perkembangan legislasi hukum Islam di Negara Indonesia yang notabene adalah negara semi sekuler.

Sejalan dengan perubahan iklim politik dan demokratisasi di awal 1980-an sampai sekarang, tampak isyarat positif bagi kemajuan perkembangan hukum Islam dalam seluruh dimensi kehidupan masyarakat. Pendekatan struktural dan harmoni dalam proses pranata 
ljtihad, Jurnal Wacana Hukum Islam dan Kemanusiaan, Volume 15, No. 1, Juni 2015: 39-60

sosial, budaya, politik, ekonomi, dan hukum, semakin membuka pintu lebar-lebar bagi upaya tranformasi hukum Islam dalam sistem hukum nasional. Tinggal bagaimana posisi politik umat Islam tidak redup dan kehilangan arah, agar tetap eksis dan memainkan peran lebih besar dalam membesarkan dan memajukan Indonesia baru yang adil dan sejahtera (Marzuki, 2013: 322). Oleh karena itu, term-term ijtihad saintifik-modern seperti primary sources, study, critical study, re-examine, non-apriori, responsive, proactive and progresive, induktive approach, dan etbic based menjadi agenda berkelanjutan dalam bingkai pembaruan hukum Islam Indonesia. Dengan demikian, hukum Islam akan dapat bicara banyak dibanding hukum Adat dan Barat di tengah gelanggang akademik dan demokratisasi hukum nasional.

\section{Penutup}

Corak pemikiran hukum Islam bila dirunut mengalami diskontinuitas sejarah dalam konsep bermazhab dan pemberlakuan hukum Islam. Dari mulai generasi mazhab klasik yang begitu membuka kebebasan ijtihad, lalu muncul ideologisasi dan stagnansi mazhab dengan wacana tertutupnya pintu ijtihad. Abad 18 ditandai dengan kolonialisme dengan pengebirian hukum Islam, taris ulur kepentingan rezim dan silang sengkarut agama-negara, hingga gerakan kebangkitan, adaptabilitas, dan pembaruan hukum Islam.

Pasca reformasi, dengan adanya GBHN 1999 mengorientasikan arah baru pembangunan hukum nasional yang benar-benar berkepribadian keindonesiaan. Hukum Islam menjadi bahan baku utama hukum nasional, selain hukum Adat dan hukum Barat. Ketiganya telah sejajar dan diimplementasikan secara eklektis sesuai sosio-kultural masyarakat dan kebutuhan zaman. Demokratisasi dan kebebasan akademik membuka peluang ketiganya untuk berbicara banyak dan memenangkan hati masyarakat. Hukum Islam memiliki kelebihan tersendiri, karena disertai dimensi transenden. Bukan hanya berkonsekuensi administratif di dunia, namun juga menuntut pertanggungjawaban ukhrawi kelak.

Namun bila membincang hukum Islam dalam ranah negara sering kali muncul sentimen yang mempertanyakan hukum Islam yang mana dimaksud. Seiring pluralitas paham, corak interpretasi, dan warna golongan keagamaan. Fikih mazhab Indonesia dalam hal ini menemui urgensinya, karena merupakan produk ijtihad yang sesuai kondisi sosio-kultural dan kepribadian bangsa. Sebagaimana mazhab klasik (ancient schools) pra-imam mazhab dengan pengakuan 
Reformulasi ijthad dalam pembaruan hukum Islam menuju hukum nasional: ... (Warkum Sumitro)

heterogenitas fikih geografis. Haluan pemikiran ini muncul seiring kesadaran para penggagasnya akan keniscayaan pergumulan fikih dengan berbagai konteks sosio-politik-historis-kultural.

Hal ini dapat dimaklumi karena konteks tempo dan lokus masyarakat tertentu meniscayakan perubahan hukum (taghayyur al-aḅkäm). Bukan memaksakan corak fikih mazhab Timur Tengah yang juga sejatinya berasal dari pengamatan empiris sosio-kultural masyarakat Timur Tengah. Kecenderungan fikih ideologis pasca imam mazhab dengan bias sikap taken for granted dan apriori terhadap kebenaran mazhab lain membawa pada masa stagnansi pemikiran dan wacana tertutupnya pintu ijtihad. Oleh karena itu, dewasa ini muncul kembali pemikiran untuk mengusung kembali fikih georafis, yang menisyacakan adaptabilitas dan pembaruan hukum Islam pada setting tertentu. Apalagi di Asia Tenggara sebagai renaissan baru Islam dunia. Khususnya di Indonesia yang memiliki dinamika pembaruan hukum Islam yang menandakan perkembangan hukum Islam di Asia Tenggara.

A. Qodri Azizy sebagai 'pewaris' geneologi pemikiran fikih (mazhab) Indonesia menawarkan Ijtihad Saintifik-Modern dengan sebelas hal yang dapat ditempuh. Pemikirannya ini bermula dari telaah kritisnya tentang konsep bermazhab yang diidentikkan dengan taqlid dan didikotomikan sama sekali dengan ijtihad. Tawaran model ijtihad Qodri dilatarbelakangi kegelisahan sosial-akademik akan entitas kehidupan pasca reformasi dan keniscayaan perubahan sosial modern. Ia bertitik tolak pada niat dan sikap batin dalam menjalankan syariat Islam lewat agenda positivisasi hukum Islam. Hal ini memerluka niat politik (political willing) dari jajaran stakeholder politik, maupun gerakan masyarakat sipil pada organisasi masyarakat (ormas) Islam maupun perorangan yang mengagendakan tajdid.

\section{Daftar pustaka}

An-Na'im, Abdullahi Ahmed. Dekonstruksi Syari'ab: Wacana Kebebasan Sipil, Hak. Asasi Manusia dan Hubungan Internasional dalam Islam. Terj. Ahmad Suaedi dan Amirudin Arrani. Yogyakarta: LKiS, 2002.

Azizy, A. Qodri. Hukum Nasional: Eklektisisme Hukum Islam dan Hukum Umum. Jakarta: Teraju, 2004.

Azizy, A. Qodri. Reformasi Bermað̧ab: Sebuah Ikbtiar Menuju Ijtihad Saintifik-Modern. Cet II. Jakarta: Teraju, 2003.

Azra, Azyumardi. Renaisans Islam Asia Tenggara: Sejarah Wacana dan Kekuasaan, Cet. II. Bandung: Remaja Rosdakarya, 2000. 
ljthad, Jurnal Wacana Hukum Islam dan Kemanusiaan, Volume 15, No. 1, Juni 2015: 39-60

Bisri, Cik Hasan. Pilar-Pilar Penelitian Hukum Islam dan Pranata Sosial. Jakarta: RajaGrafindo Persada, 2004.

Fanani, Muhyar. Membumikan Hukum Langit: Nasionalisasi Hukum Islam dan Islamisasi Hukum Nasional. Yogyakarta: Tiara Wacana, 2008.

Fuad, Mahsun. Hukum Islam Indonesia: Dari Nalar Partisipatoris Hingga Nalar Emansipatoris. Yogyakarta: LKiS, 2005.

Iqbal, Muhammad. Hukum Islam Indonesia Modern: Dinamika Pemikiran dari Fikib Klasik ke Fikih Indonesia. Tangerang: Gaya Media Pratama, 2009.

Khallaf, 'Abd Al-Wahhab. Tlm Ușul al-Fikih. Kuwait: Dar Al Qalam, 1978.

Madjid, Nurcholish. Islam Doktrin dan Peradaban: Sebuab Telaab Kritis tentang Masalah Keimanan, Kemanusiaan, dan Kemodernan, Cet. III. Jakarta: Paramadina, 1995.

Marzuki. Pengantar Studi Hukum Islam: Prinsip Dasar Memahami Berbagai Konsep dan Permasalahan Hukum Islam di Indonesia. Yogyakarta: Penerbit Ombak, 2013.

Mawardi, Ahmad Imam. Fikih Minoritas: Fikih Al-Aqliyat dan Evolusi Maqsid Al-Syari'ah dari Konsep ke Pendekatan. Yogyakarta: LKiS, 2010.

Najib, Agus Moh. Pengembangan Metodologi Fikib Indonesia dan Kontribusinya Bagi Pembentukan Hukum Nasional. T.tp: Kementerian Agama RI, 2011.

Rofiq, Ahmad. Pembaruan Hukum Islam di Indonesia. Yogyakarta: Gama Media, 2001.

Rosyadi, Rahmat dan Rais Ahmad. Formalisasi Syariat Islam dalam Perspektif Tata Hukum Indonesia. Bogor: Ghalia Indonesia, 2006.

Shiddiqi, Nourozzaman. Fikih Indonesia: Penggagas dan Gagasannya. Yogyakarta: Pustaka Pelajar, 1997.

Suma, Muhammad Amin. Hukum Keluarga Islam di Dunia Islam. Jakarta: RajaGrafindo Persada, 2004.

Sumitro, Warkum, dkk. Transformasi Peradilan Agama dalam Sistem Peradilan Nasional: Mengulas Dinamika Reposisi Peradilan Agama ke dalam One Roof System di Indonesia. Yogyakarta: Ar-Ruzz Media, 2014.

Syarifuddin, Amir. Meretas Kebekuan Ijtibad: Isu-isu Penting Hukum Islam Kontemporer di Indonesia. Jakarta: Ciputat Pers, 2002.

Syaukani, Imam. Rekonstruksi Epistemologi Hukum Islam. Jakarta: Rajawali Press, 2006.

Tebba, Sudirman (Ed.). Perkembangan Mutakbir Hukum Islam di Asia Tenggara: Studi Kasus Hukum Keluarga dan Pengkodifikasiannya. Bandung: Mizan, 1993.

Zed, Mestika. Metode Penelitian Kepustakaan. Jakarta: Yayasan Obor Indonesia, 2008. 